\title{
EVALUATION OF CELL DISRUPTION FOR PARTIAL ISOLATION OF INTRACELLULAR PYRUVATE DECARBOXYLASE ENZYME BY SILVER NANOPARTICLES METHOD
}

\author{
J. Tangtua ${ }^{a}$, C. Techapun ${ }^{b}$, R. Pratanaphon ${ }^{b}$, A. Kuntiya ${ }^{b}$, V. Sanguanchaipaiwong ${ }^{c}$,

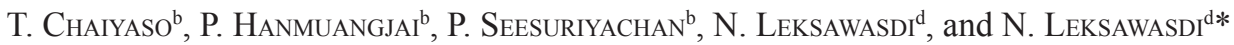 \\ aDivision of Food Science and Technology, Faculty of Science and Technology, \\ Kamphaeng Phet Rajabhat University, Kamphaeng Phet, 62000. Thailand \\ ${ }^{\mathrm{b}}$ Division of Biotechnology \& Bioprocess Research Cluster, School of Agro-Industry, Faculty of Agro-Industry, \\ Chiang Mai University, Chiang Mai, 50100. Thailand \\ ${ }^{\mathrm{c}}$ Department of Applied Biology \& Bioprocess Research Cluster, Faculty of Science, King Mongkut's Institute of \\ Technology Ladkrabang, Bangkok, 10520. Thailand \\ ${ }^{\mathrm{d}}$ Division of Food Engineering, School of Agro-Industry, Faculty of Agro-Industry, Chiang Mai University, \\ Chiang Mai, 50100. Thailand
}

(Received: 11 February 2014; accepted: 14 April 2014)

Candida tropicalis TISTR 5350 was used in the comparison of seven concentration levels of silver nanoparticles $(0$, $5,10,15,20,25$, and $30 \mu \mathrm{g} \mathrm{ml}^{-1}$ ) for cell disruption methods. The optimized cell disruption strategy was selected based on the optimal protein yield and biological activity. The maximum volumetric and specific pyruvate decarboxylase (PDC, EC 4.1.1.1) activities $\left(0.53 \pm 0.05 \mathrm{U} \mathrm{ml}^{-1}\right.$ and $0.17 \pm 0.02 \mathrm{U} \mathrm{mg}^{-1}$ protein, respectively) were observed at $15 \mu \mathrm{g} \mathrm{ml}^{-1}$ silver nanoparticles. The silver nanoparticle concentration level of $15 \mu \mathrm{g} \mathrm{ml}^{-1}$ was investigated further by comparing the reaction mixtures at different time intervals of $0,1,2,3,4,5$, and $6 \mathrm{~min}$. The result showed that the highest specific PDC activity of $0.39 \pm 0.01 \mathrm{U} \mathrm{mg}^{-1}$ protein was obtained from mixing for 3 min. This was not significantly different $(\mathrm{P} \leq 0.05)$ from other mixing time intervals. activity

Keywords: silver nanoparticles, cell disruption, pyruvate decarboxylase, protein concentration, enzyme

The disruption of cell walls is an important step to isolate and extract substances from inside the cells and for preparation of intracellular products for biopharmaceutical usage. The overall goal in cell disruption is to obtain the desired product from within the cells, thus cell walls must be disrupted to release the contents of the cells. In essence, the objective of cell disruption is to achieve high protein recovery, while maintaining biological activity and high reproducibility (GERDEA et al., 2012).

Current commercial phenylacetylcarbinol (PAC) production processes involve the use of fermenting yeast to produce sufficient biomass for the associated accumulation of the intracellular pyruvate and the induction of PDC synthesis in a fed-batch process (TANGTUA et al., 2013). An enzymatic process based on extracted pyruvate decarboxylase (PDC, EC 4.1.1.1) overcomes the problem of by-product benzyl alcohol formation, since there is no regeneration of electron donors (e.g. NADH) in the cell-free system. Up to $28.6 \mathrm{~g} \mathrm{l}^{-1} \mathrm{PAC}$ with a yield on initial benzaldehyde of $95.3 \%$ has been reported for the cell-free process using partially purified Candida utilis PDC (SHIN \& Rogers, 1996). In addition, a possible disadvantage of using whole cells as biotransformation catalysts was putative mass transfer

\footnotetext{
* To whom correspondence should be addressed.

Phone: +66-87-6985528; fax: +66-53-94-8206; e-mail: noppol@hotmail.com
}

0139-3006/\$20.00 @ 2015 Akadémiai Kiadó, Budapest 
limitation of substrates and products across the cell envelope (SATIANEGARA, 2006; SAmBerg et al., 2010). Silver nanoparticles are applied with various technologies and its application for antimicrobial coatings is increasingly common (SAMBERG et al., 2010). Silver ions and silver salts have been used for decades as antimicrobial agents in various fields because of the growth inhibiting property against microorganisms. Silver ions may bind non-specifically to cell surfaces, causing some disruption to the cellular membrane function and allowing the silver ions to penetrate the microbial structure. The electrostatic interaction between positively charged ions, such as silver $\left(\mathrm{Ag}^{+}\right)$, and the negatively charged cell wall of microorganisms leads to the built up of stress and eventual to the breakdown of cell walls (VARNER \& SANFORD, 2010). The mechanisms of such deactivation support the hypothesis that silver nanoparticles are suitable for new cell disruption methods.

The objective of this research was to consider the best concentration levels of silver nanoparticles and mixing time interval for partial isolation of intracellular PDC enzyme.

\section{Materials and methods}

\subsection{Microorganism}

C. tropicalis TISTR 5350 from Thailand Institute of Scientific and Technological Research (TISTR) was cultivated in $10 \mathrm{ml}$ inoculation medium for later propagation at a $100 \mathrm{ml}$ scale. The cultivation was carried out at $30^{\circ} \mathrm{C}$ on a rotary shaker at 200 r.p.m. for $24 \mathrm{~h}$ (LALUCE et al., 2009). The cell pellet was separated by centrifugation at $2822 \times g$ for $15 \mathrm{~min}$ using a centrifuge machine. Cell pellet was recovered from $10 \mathrm{ml}$ culture broth and washed twice with $10 \mathrm{ml}$ distilled water. This was performed prior to resuspending in citrate buffer ( $\mathrm{pH} 6.0)$.

\subsection{Silver nanoparticles}

Silver nanoparticles were obtained from the courtesy of Sensor Research Unit, Department of Chemistry, Faculty of Science, Chulalongkorn University. Colloidal suspension of silver nanoparticles was stabilized in $2 \%(\mathrm{w} / \mathrm{v})$ soluble starch. The transmission electron microscopy (TEM) image of the silver synthesized is presented in Figure 1 and indicates well dispersed particles. These were spherical in shape with an average diameter of $6.03 \pm 2.60 \mathrm{~nm}$. The appearance of the solution was dark yellow liquid.

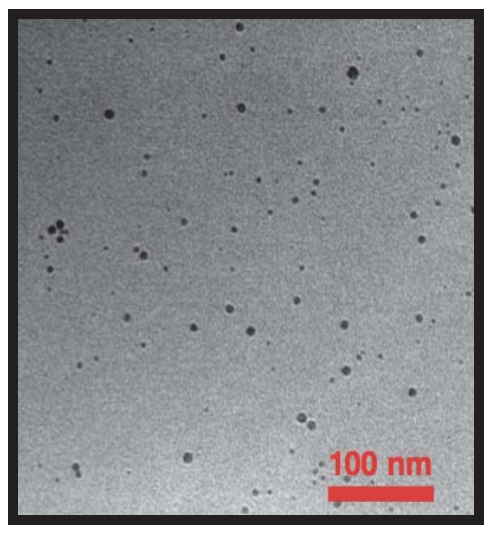

Fig. 1. TEM image of spherical silver nanoparticles 


\subsection{Estimation of silver nanoparticle concentration for cell disruption}

Various concentration levels of silver nanoparticles at $0,5,10,15,20,25$, and $30 \mu \mathrm{g} \mathrm{ml}^{-1}$ were evaluated for the microbial cell disruption based on the protein yield and biological activity (LeE et al., 2010). Silver nanoparticle solution was added in the cell suspension, which was recovered from $10 \mathrm{ml}$ culture broth prior to resuspension in citrate buffer $(\mathrm{pH} \mathrm{6.0)}$ ). The mixture was vortexed at a maximum speed $(2350 \times \mathrm{g})$ for $1 \mathrm{~min}$. After the sample was cooled down for $2 \mathrm{~min}$ in ice-water mixture. The supernatant was separated by centrifugation for subsequent enzyme activity and protein concentration analyses. The best concentration level of silver nanoparticles was selected based on PDC activity for comparison of time dependent interaction of silver nanoparticles for cell disruption.

\subsection{Time dependent interaction of silver nanoparticles}

The most appropriate concentration level of silver nanoparticles was suspended in cell suspension to perform the time dependent cell disruption study of silver nanoparticles. The mixture was vortexed at a maximum speed for 1 min with varying time interval of $0,1,2,3$, 4,5 , and $6 \mathrm{~min}$. After each time interval treatment, cell debris was removed by centrifugation at $2822 \times g$ for $15 \mathrm{~min}$ and the supernatant was collected and stored at $-20^{\circ} \mathrm{C}$ for enzyme assays and protein concentration estimation.

\subsection{Analytical methods}

PDC carboligase activity was measured as a formation of PAC in 20 min at $25{ }^{\circ} \mathrm{C}$ from $80 \mathrm{mM}$ benzaldehyde and $200 \mathrm{mM}$ pyruvate in carboligase buffer. One unit (U) carboligase activity was defined as the amount of enzyme that produced $1 \mu \mathrm{mol}$ PAC from pyruvate and benzaldehyde per min at $\mathrm{pH} 6.4$ and $25^{\circ} \mathrm{C}$ in a carboligase assay as specified by Rosche and co-workers (2002). The detection of protein concentration was performed according to BRADFORD (1976) using bovine serum albumin for construction of a standard curve. Specific carboligase activity was determined based on protein concentrations in the sample and expressed in units of enzyme per milligram protein $\left(\mathrm{U} \mathrm{mg}^{-1}\right)$.

\section{Results and discussion}

\subsection{Estimation of silver nanoparticle concentration for cell disruption}

Seven concentration levels of silver nanoparticles, namely, 0, 5, 10, 15, 20, 25, and 30 $\mu \mathrm{g} \mathrm{ml}^{-1}$ were evaluated for the microbial cell disruption based on the biological activity and product yield. The highest volumetric and specific PDC activities $\left(0.53 \pm 0.05 \mathrm{U} \mathrm{ml}^{-1}\right.$ and $0.17 \pm 0.02 \mathrm{U} \mathrm{mg}^{-1}$ protein, respectively) were observed at $15 \mu \mathrm{g} \mathrm{ml}^{-1}$ of silver nanoparticle concentration as indicated in Table 1 . This was different statistically $(\mathrm{P} \leq 0.05)$ from the lower concentration level of 0,5 , and $10 \mu \mathrm{g} \mathrm{ml}^{-1}$ at $0.00 \pm 0.00,0.14 \pm 0.01$, and $0.12 \pm 0.01 \mathrm{U} \mathrm{mg}^{-1}$ protein, respectively. SondI and SALOPEK-SONDI (2004) suggested that the antimicrobial activity was dependent on the concentration of silver nanoparticles, and was closely associated with the formation of pits in the cell wall. The accumulation of silver nanoparticles in the bacterial membrane caused increasing permeability, releasing desired biomolecules from within the cells. The mechanism of silver ions inhibitory effects included the degradation effect of the membrane structure through the electrostatic attraction between negatively 
charged cell membranes and positively charged nanoparticles (KIM et al., 2007). PANACEK and co-workers (2009) revealed that Candida spp. was inhibited by silver nanoparticles at very low concentration levels. The minimum inhibitory concentration (MIC) was found at 1.69 $\mu \mathrm{g} \mathrm{ml}^{-1}$ for the growth of C. parapsilosis. However, they also suggested that silver nanoparticle inhibition was dependent on the yeast species tested. Ionic silver caused death of $C$. tropicalis immediately even at such low concentrations as $0.84 \mathrm{mg} \mathrm{l}^{-1}$ (KvITEK et al., 2011). PRASAD and co-workers (2011) stated that silver nanoparticles showed good antimicrobial activity against Escherichia coli, Bacillus cereus, and Candida tropicalis.

Table 1. Comparative effect of different silver nanoparticle concentration levels on PDC activity and protein concentration

\begin{tabular}{|c|c|c|c|c|c|c|}
\hline \multirow{2}{*}{$\begin{array}{l}\text { Silver nanoparticle } \\
\text { concentration levels } \\
\left(\mu \mathrm{g} \mathrm{ml}^{-1}\right) \\
0\end{array}$} & \multicolumn{2}{|c|}{$\begin{array}{l}\text { Volumetric PDC activity } \\
\qquad\left(\mathrm{U} \mathrm{ml}^{-1}\right)\end{array}$} & \multicolumn{2}{|c|}{$\begin{array}{l}\text { Specific PDC activity } \\
\text { (U mg }{ }^{-1} \text { protein) }\end{array}$} & \multicolumn{2}{|c|}{$\begin{array}{l}\text { Protein concentration } \\
\qquad\left(\mathrm{mg} \mathrm{ml}^{-1}\right)\end{array}$} \\
\hline & $0.00 \pm 0.00$ & D & $0.00 \pm 0.00$ & $\mathrm{C}$ & $0.00 \pm 0.00$ & $\mathrm{E}$ \\
\hline 5 & $0.34 \pm 0.03$ & B & $0.14 \pm 0.01$ & $\mathrm{AB}$ & $2.51 \pm 0.06$ & D \\
\hline 10 & $0.36 \pm 0.02$ & B & $0.12 \pm 0.01$ & B & $3.03 \pm 0.01$ & C \\
\hline 15 & $0.53 \pm 0.05$ & A & $0.17 \pm 0.02$ & A & $3.19 \pm 0.07$ & B \\
\hline 20 & $0.20 \pm 0.03$ & $\mathrm{C}$ & $0.05 \pm 0.01$ & $\mathrm{C}$ & $3.63 \pm 0.10$ & A \\
\hline 25 & $0.11 \pm 0.02$ & $\mathrm{C}$ & $0.03 \pm 0.01$ & $\mathrm{C}$ & $3.68 \pm 0.07$ & A \\
\hline 30 & $0.10 \pm 0.02$ & $\mathrm{C}$ & $0.03 \pm 0.01$ & $\mathrm{C}$ & $3.49 \pm 0.12$ & B \\
\hline
\end{tabular}

The number with the same alphabet $(\mathrm{A}-\mathrm{E})$ indicated no significant difference $(\mathrm{P}>0.05)$ for comparison between different rows of the same columns.

The higher concentration levels $\left(20,25\right.$, and $\left.30 \mu \mathrm{g} \mathrm{ml}^{-1}\right)$ of silver nanoparticles were inversely proportional to the PDC activity with the corresponding levels of $0.20 \pm 0.03$, $0.11 \pm 0.02$, and $0.10 \pm 0.02 \mathrm{U} \mathrm{ml}^{-1}$. This was compared to PAC production levels of $1.78 \pm 0.31$, $1.02 \pm 0.15$, and $0.88 \pm 0.18 \mathrm{mM}$, respectively. This might be due to the high reactivity of silver ions, which readily bounded to electron donor groups. The prime targets were thiol groups (-SH), which are commonly found in enzymes within the microbe (MARIA et al., 2010). This caused the enzyme to denature with certain degree of microbial cell disruption at the higher silver nanoparticle concentration level of $15 \mu \mathrm{g} \mathrm{ml}^{-1}$.

The obtained results showed that silver nanoparticles at $15 \mu \mathrm{g} \mathrm{ml}^{-1}$ proved to be more effective for C. tropicalis TISTR 5350 cell disruption than at other concentration levels.

\subsection{Time dependent interaction of silver nanoparticles}

Silver nanoparticles at $15 \mu \mathrm{g} \mathrm{ml}^{-1}$ concentration were mixed into the microbial cell suspension. The highest PDC activity of $0.39 \pm 0.01 \mathrm{U} \mathrm{mg}$ protein ${ }^{-1}$ was observed when treating cells with silver nanoparticles for $3 \mathrm{~min}$ (Table 2). The protein concentration, although increased with time, was inversely proportional to PDC activity when the treatment was carried out for longer than $3 \mathrm{~min}$. It is possible that the membrane of microorganism contains a number of sulphate-containing functional groups that can interact with silver ions and results in the 
changes of the membrane morphology and membrane vulnerability that allowed penetration for silver ions. Sulphate-groups in residue 221 of yeast PDC, which are located in the vicinity of the active site and are involved in the activation by substrate (BABURINA et al., 1994), could also interact with silver ions. This might contribute to the partial loss of PDC activity (Tolaymat et al., 2010). The morphological differences between control (no treatment) and treated $\left(15 \mu \mathrm{g} \mathrm{ml}^{-1}\right.$ silver nanoparticles for $\left.3 \mathrm{~min}\right)$ C. tropicalis TISTR 5350 cells were observed under LV-SEM (Figs 2-3). The direct exposure to silver nanoparticles resulted in some distortion and collapsing of some cells as silver ions could easily interact with membrane and were able to penetrate into the cells.

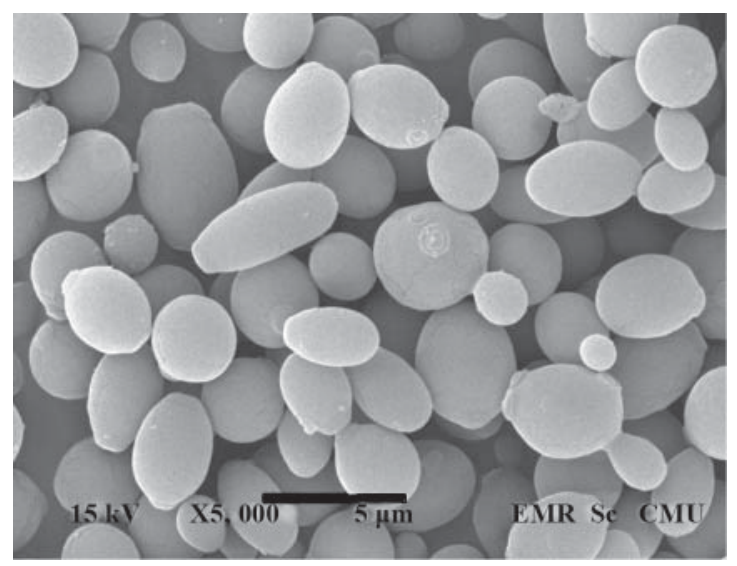

Fig. 2. LV-SEM photomicrograph of C. tropicalis TISTR 5350 before treatment (control)

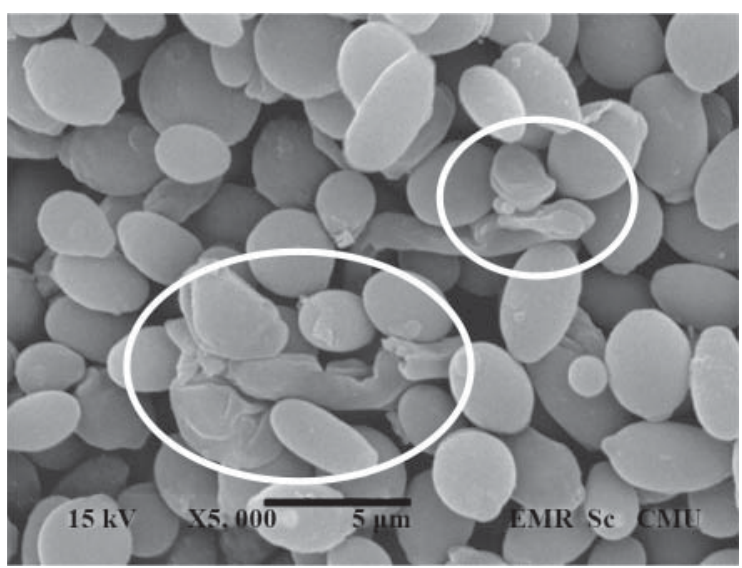

Fig. 3. LV-SEM photomicrographs of C. tropicalis TISTR 5350 cells after treatment with $1.5 \mu \mathrm{g} \mathrm{m} \mathrm{l}^{-1}$ silver nanoparticles for $3 \mathrm{~min}$ 
Table 2. Comparative effect of different time interval on PDC activity and protein concentration

\begin{tabular}{lcccccc}
\hline $\begin{array}{l}\text { Time mixing } \\
\text { interval }(\mathrm{min})\end{array}$ & $\begin{array}{c}\text { Volumetric PDC activity } \\
\left(\mathrm{U} \mathrm{ml}^{-1}\right)\end{array}$ & \multicolumn{2}{c}{$\begin{array}{c}\text { Specific PDC activity } \\
\left(\mathrm{U} \mathrm{mg}^{-1} \text { protein }\right)\end{array}$} & $\begin{array}{c}\text { Protein concentration } \\
\left(\mathrm{mg} \mathrm{m}^{-1}\right)\end{array}$ \\
\hline 0 & $0.49 \pm 0.01$ & $\mathrm{C}$ & $0.27 \pm 0.01$ & $\mathrm{C}$ & $1.80 \pm 0.01$ & $\mathrm{BC}$ \\
1 & $0.55 \pm 0.02$ & $\mathrm{~B}$ & $0.27 \pm 0.01$ & $\mathrm{C}$ & $0.14 \pm 0.01$ & $\mathrm{D}$ \\
2 & $0.57 \pm 0.01$ & $\mathrm{~B}$ & $0.33 \pm 0.01$ & $\mathrm{~B}$ & $1.73 \pm 0.02$ & $\mathrm{BC}$ \\
3 & $0.66 \pm 0.01$ & $\mathrm{~A}$ & $0.39 \pm 0.01$ & $\mathrm{~A}$ & $1.70 \pm 0.03$ & $\mathrm{BC}$ \\
4 & $0.63 \pm 0.02$ & $\mathrm{~A}$ & $0.32 \pm 0.01$ & $\mathrm{~B}$ & $1.94 \pm 0.01$ & $\mathrm{~B}$ \\
5 & $0.51 \pm 0.02$ & $\mathrm{BC}$ & $0.31 \pm 0.01$ & $\mathrm{~B}$ & $1.67 \pm 0.01$ & $\mathrm{C}$ \\
6 & $0.37 \pm 0.02$ & $\mathrm{D}$ & $0.17 \pm 0.01$ & $\mathrm{D}$ & $2.15 \pm 0.03$ & $\mathrm{~A}$ \\
\hline
\end{tabular}

The number with the same alphabet $(A-D)$ indicated no significant difference $(\mathrm{P}>0.05)$ for comparison between different rows of the same columns.

\section{Conclusions}

The effect of silver nanoparticles to the observed PDC activity was both dose and time dependent. The maximum level of PDC activity $\left(0.66 \pm 0.01 \mathrm{U} \mathrm{ml}^{-1}\right.$ and $0.39 \pm 0.01 \mathrm{U} \mathrm{mg}^{-1}$ protein) was observed at $15 \mu \mathrm{g} \mathrm{ml}^{-1}$ silver nanoparticle concentration for $3 \mathrm{~min}$. Silver nanoparticles could thus also as an alternative be used to disrupt cells by increasing the permeability of the cell membrane, which contributes to the leakage of cell contents. Moreover, silver nanoparticles method could reduce time investment and renders unavailable equipment unnecessary for cell disruption method. Silver nanoparticles method is also suitable for application to commercial processes, and it is an uncomplicated process with low costs. To improve the current research, further investigation, such as elimination of silver contaminants from PDC enzyme, should be done for the preservation of activity.

The authors gratefully acknowledge the financial support of the National Research University (NRU), the Office of Higher Education Commission (OHEC), the Ministry of Education, Thailand, the National Research Council of Thailand (NRCT). The authors thank the Thailand Institute of Scientific and Technological Research (TISTR) for the supplying of microbial strains for this project, as well as Bioprocess Research Cluster (BRC), School of Agro-Industry, Faculty of Agro-Industry, Chiang Mai University. We would also like to thank Associate Professor SANONG EkgAsIT the courtesy of Sensor Research Unit, Department of Chemistry, Faculty of Science, Chulalongkorn University, Thailand to provide the silver nanoparticles used in the current study.

\section{References}

Baburina, I., GaO, Y., Hu, Z., Jordan, F., Hohmann, S. \& Furey, W. (1994): Substrate activation of brewer's yeast pyruvate decarboxylase is abolished by mutation of cysteine 221 to serine. Biochem., 33, 5630-5635.

BRADFORD, M.M. (1976): A rapid and sensitive method for the quantitation of microgram quantities of protein utilizing the principle of protein-dye binding. Anal. Biochem., 72, 248-254.

Gerdea, J.A., Montalbo-Lomboya, M., YaoA, L., Grewell, D. \& Wanga, T. (2012): Evaluation of microalgae cell disruption by ultrasonic treatment. Bioresource Technol., 125, 175-181.

Kim, J.S., KuK, E., Yu, K.N., Kim, J.H., Park, S.J., Lee, H.J., Kim, S.H., PARK, Y.K., Park, Y.H., Hwang, C.Y., Kim, Y.K., LeE, Y.S., JEONG, D.H. \& Сно, M.H. (2007): Antimicrobial effects of silver nanoparticles. Nanomed.Nanotechnol., 3, 95-101. 
Kvitek, L., Panacek, A., Prucek, R., Soukupova, J., Vanickova, M., Kolar, M. \& Boril, R.Z. (2011): Antibacterial activity and toxicity of silver - nanosilver versus ionic silver. J. Phys. Conf. Ser., 304, 12-29.

Laluce, C., Tognoldi, J.O., De Oliveira, K.F., Souza, C.S. \& Morais, M.R. (2009): Optimization of temperature, sugar concentration, and inoculum size to maximize ethanol production without significant decrease in yeast cell viability. Appl. Microbiol. Biot., 83, 627-637.

Lee, J., Kim, K.J., Sung, W.S., Kim, J.K. \& Lee, D.G. (2010): The silver nanoparticle (nano-Ag): A new model for antifungal agents. Available at.: http://www.intechopen.com/books/silver-nanoparticles/the-silvernanoparticle-nano-ag-a-new-model-for-antifungal-agents. Last accessed 5 Oct 2010.

Maria, L.C.S., Santos, A.L.C., Oliveira, P.C., Valle, A.S.S., Barud, H.S., Messaddeq, Y. \& Ribeiro, S.J.L. (2010): Preparation and antibacterial activity of silver nanoparticles impregnated in bacterial cellulose. Polimeros, 20, $72-77$.

Panacek, A., Kolár, M., Vecerová, R., Prucek, R., Soukupová, J., Krystof, V., Hamal, P., Zboril, R. \& Kvítek, L. (2009): Antifungal activity of silver nanoparticles against Candida spp. Biomaterials, 30, 6333-6340.

Prasad, T.N.V.K.V., Elumalai, E.K. \& Khateeja, S. (2011): Evaluation of the antimicrobial efficacy of phytogenic silver nanoparticles. Asian Pac. J. Trop. Biomed., 1, S82-S85.

Rosche, B., Leksawasdi, N., Sandford, V., Breuer, M., Hauer, B. \& Rogers, P.L. (2002): Enzymatic (R)phenylacetylcarbinol production in benzaldehyde emulsions. Appl. Microbiol. Biot., 60, 94-100.

Samberg, M.E., Oldenburg, S.J. \& Monteiro-Riviere, N.A. (2010): Evaluation of silver nanoparticle toxicity in skin in vivo and keratinocytes in vitro. Environ. Health Persp., 118, 407-413.

Satianegara, G. (2006): Comparative studies on different enzyme preparations for (R)-phenylacetylcarbinol production. Dissertation, University of New South Wales, Sydney, Australia. 162 pages.

Shin, H.S. \& Rogers, P.L. (1996): Production of $L$-phenylacetylcarbinol ( $L$-PAC) from benzaldehyde using partially purified pyruvate decarboxylase (PDC). Biotechnol. Bioeng., 49, 52-62.

Sondi, I. \& SALOPEK-Sondi, B. (2004): Silver nanoparticles as antimicrobial agent: A case study on E. coli as a model for Gram-negative bacteria. J. Colloid Interf. Sci., 275, 177-182.

Tangtua, J., Techapun, C., Pratanaphon, R., Kuntiya, A., Chaiyaso, T., Hanmuanguai, P., Seesuriyachan, P. \& LEKSAWASDI, N. (2013): Screening of 50 microbial strains for production of ethanol and $(R)$-phenylacetylcarbinol. Chiang Mai J. Sci., 40, 299-304.

Tolaymat, T.M., Amro, M., El Badawy, A.M., Ash Genaidy, A., Scheckel, K.G., Luxton, T.P. \& Suidan, M. (2010): An evidence-based environmental perspective of manufactured silver nanoparticle in syntheses and applications: A systematic review and critical appraisal of peer-reviewed scientific papers. Sci. Total Environ., 408, 999-1006.

VARNER, K. \& SANFORD, J. (2010): State of the science literature review: everything nanosilver and more. Available from: http://www.epa.gov/ nanoscience /files/ NanoPaper1.pdf. Last accessed 3 Aug 2010. 